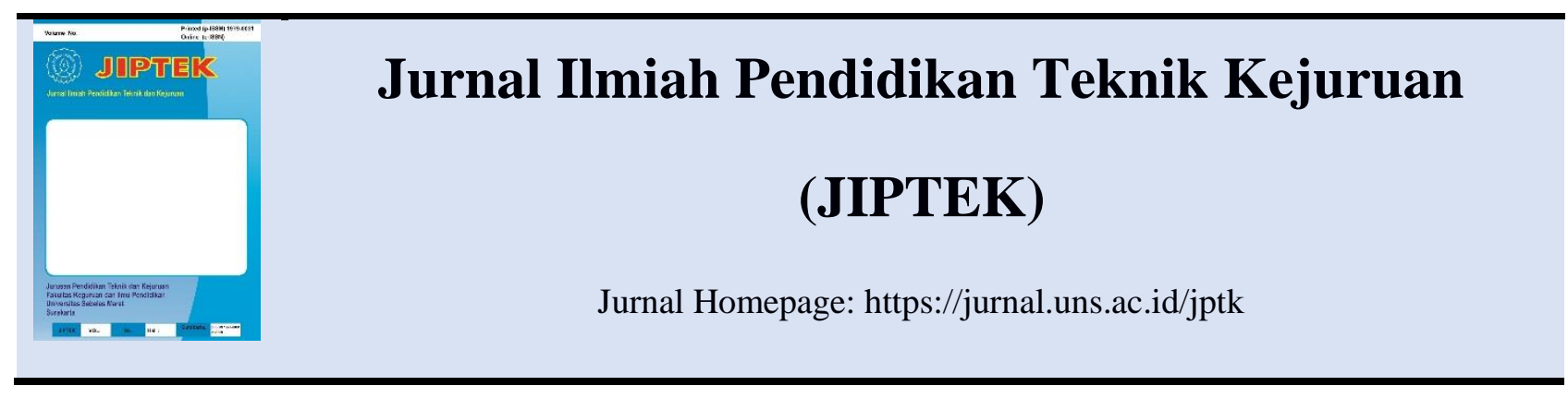

\title{
PENINGKATAN KOMPETENSI PESERTA DIDIK PADA MATA PELAJARAN PEMROGRAMAN DASAR MENGGUNAKAN MODEL KOOPERATIF TIPE STAD BERLATAR MUSIK KLASIK KELAS X MULTIMEDIA 1 SMK NEGERI 3 SURAKARTA
}

\author{
${ }^{1}$ Agung Wiratmo, ${ }^{2}$ Basori, ${ }^{3}$ Dwi Maryono \\ 1,2,3Pendidikan Teknik Informatika dan Komputer, Universitas Sebelas Maret \\ Email: 4a.wiratmo@gmail.com
}

\begin{abstract}
Abstrak
Penelitian ini bertujuan untuk meningkatkan kompetensi (1) kognitif; (2) psikomotorik; (3) afektif pada mata pelajaran pemrograman dasar setelah menggunakan model kooperatif tipe STAD berlatar musik klasik; Penelitian ini merupakan penelitian tindakan kelas dengan pelaksanaan selama 2 siklus. Penelitian ini menggunakan model kooperatif tipe STAD dengan latar musik klasik. Subjek penelitian ini adalah seluruh siswa kelas X Multimedia 1 di SMK Negeri 3 Surakarta. Penggumpulan data dilakukan dengan teknik observasi untuk data kompetensi afektif peserta didik, teknik tes untuk data kompetensi kognitif dan psikomotorik, dan teknik angket untuk data efektivitas musik klasik dalam pembelajaran terhadap ketenangan dan konsentrasi. Analisis data yang digunakan adalah analisis data diskriptif komparatif. Hasil penelitian sebagai berikut. (1) peningkatan kompetensi kognitif peserta didik belum mencapai indikator (Pratindakan 0\%, Siklus I 18.518\%, dan Siklus II 10\%). (2) peningkatan kompetensi psikomotorik peserta didik mencapai indikator (Pratindakan 33.33\%, Siklus I 74.074\%, dan Siklus II 76.67\%). (3) peningkatan pada kompetensi afektif peserta didik mencapai indikator (Pratindakan 40\%, Siklus I 53.125\%, dan Siklus II 80\%).
\end{abstract}

Kata Kunci: Kompetensi, model kooperatif, Musik Klasik, Pemrograman Dasar, STAD

\begin{abstract}
The purpose of this research is to improve student's competence of (1) cognitive; (2) psychomotor; (3) affective; on the basic programming subjects using cooperative learning model ,STAD type with classical music background; This research is class action reserch which was conducted in two cycles. This research used cooperative learning model STAD type with classical music background. The subject of this research was students of class X multimedia 1 in SMK N 3 Surakarta. Data were collected by observation, for the data of students affective competence, tests for data of students cognitive and psychomotor competencies, and questionnaire for effectiveness data of classical music toward the tranquility and the concentration. Those data were analyzed with descriptive comparative data analysis. The results showed that (1) there were enhancement cognitive competency although it had not reached indicators (pretest 0\%, Cycle I 18.518\%, and Cycle II 10\%). (2), there were enhancement in psychomotor competency which has also reached indicators (pretest 33.33\%, Cycle I 74.074\%, and Cycle II 76.67\%). (3) there were enhancement in affective competency which has also reached indicators (pretest 40\%, Cycle I 53.125\%, and Cycle II 80\%).
\end{abstract}

Keywords: Basic programming, classical music, competency, cooperative model, STAD. 


\section{PENDAHULUAN}

\section{Latar Belakang}

Berdasarkan Undang-Undang Nomor 2 Tahun 1989, Pendidikan merupakan usaha sadar untuk menyiapkan peserta didik melalui kegiatan bimbingan, pengajaran, dan atau latihan bagi peranannya di masa yang akan datang. Oleh karenanya kemajuan suatu bangsa dapat dilihat dan diukur dari kemajuan pendidikan bangsa tersebut. Jalur pendidikan di Indonesia salah satunya adalah jalur formal seperti pendidikan menengah kejuruan dengan contoh SMK Negeri 3 Surakarta.

Salah satu mata pelajaran di SMK Negeri 3 Surakarta adalah pemrograman dasar. Selama survei di SMK Negeri 3 Surakarta, peneliti mendapatkan data kompetensi peserta didik kelas $\mathrm{X}$ Multimedia 1 dalam ranah kognitif, psikomotorik, dan afektif. Data kompetensi kognitif diperoleh dari dokumen arsip hasil ujian mid semester, presentase kelulusan peserta didik $6,25 \%$. Data kompetensi psikomotorik juga diperoleh dari dokumen arsip hasil praktik, presentase kelulusan peserta didik $6,45 \%$. Data kompetensi afektif diperoleh dari observasi selama survei, presentase kelulusan peserta didik $31,25 \%$. Berdasarkan observasi pada survei, peneliti menduga penyebab dari permasalahan pada kompetensi kognitif peserta didik adalah metode yang digunakan guru belum tepat. Metode yang digunakan oleh guru berupa metode ceramah yang menyebabkan guru mendominasi dalam pembelajaran. Penyebab lainnya adalah konsentrasi peserta didik sudah berkurang. Hal tersebut disebabkan karena mata pelajaran pemrograman dasar terletak pada jam ke-11 dan ke-12. Hipotesis ini bersumber dari penelitian Lamba,dkk (2014:1-4) yang menyatakan bahwa sebagian besar siswa kehilangan perhatian dan konsentrasi selama kegiatan belajar mengajar yang panjang.penyebab permasalahan dari kompetensi psikomotorik adalah peserta didik kurang menguasai materi. Sehingga dalam praktiknya, peserta didik merasa kesulitan dalam merencanakan pemecahan masalah dan penanganan error. Peserta didik juga kurang teliti dalam mengerjakan tugas, konsentrasi peserta didik dalam mengikuti proses pembelajaran sudah berkurang, dan peserta didik kurang percaya diri terhadap pemecahan masalah yang dibuatnya. penyebab permasalahan dari kompetensi afektif pada peserta didik adalah kurangnya keaktifan dari peserta didik dalam proses pembelajaran. Penyebabnya adalah peserta didik terlihat kurang berminat terhadap pelajaran pemrograman dasar serta motivasi untuk menguasai materi pada mata pelajaran pemrograman dasar kurang. Sehingga peserta didik dalam proses pembelajaran kurang rasa ingin tahu.

Menurut peneliti penggunaan model yang tepat dalam pembelajaran dapat menjadi salah satu solusi akan permasalahan tersebut. Salah satu model yang diperkirakan dapat menyelesaikan permasalahan tesebut adalah model kooperatif tipe STAD. Dengan menerapkan model kooperatif tipe STAD diharapkan dapat meningkatkan kompetensi kognitif peserta didik. Hal tersebut dikarenakan dalam model tersebut peserta didik harus saling mendukung dan membantu satu sama lain dalam menguasai materi yang disampaikan oleh guru. Kompetensi psikomotorik peserta didik diharapkan dapat meningkat. Hal ini dikarenakan dalam model tersebut terdapat sesi diskusi. Dalam sesi diskusi peserta didik dapat bertukar pendapat tentang cara pengerjaan tugas yang diberikan oleh guru. kompetensi afektif peserta didik diharapkan dapat meningkat dikarenakan dalam model tersebut berorientasi pembelajaran dengan peserta didik sebagai pusatnya. Peserta didik dituntut untuk aktif dalam setiap tahapannya.

Penggunaan musik klasik sebagai latar proses pembelajaran diduga dapat meningkatkan konsentrasi dan ketenangan dalam pembelajaran. Campbell (2002:220) mengungkapkan bahwa musik dapat membawa suasana positif dan santai bagi kebanyakan kelas. Campbell (2002:97) musik klasik memiliki kejernihan, keanggunan, dan kebeningan. Musik ini mampu memperbaiki konsentrasi, ingatan dan persepsi spasial.

Berdasarkan uraian di atas, peneliti dalam menyelesaikan tugas akhir mengambil judul "Peningkatan Kompetensi Peserta Didik Pada Mata Pelajaran Pemrograman Dasar Menggunakan Model Kooperatif Tipe STAD Berlatar Musik Klasik Kelas X Multimedia 1 SMK Negeri 3 Surakarta".

\section{Tujuan Penelitian}

Berdasarkan latar belakang, maka tujuan dari penelitian untuk meningkatan (1) kompetensi kognitif (2) kompetensi psikomotorik (3) kompetensi afektif peserta didik pada mata pelajaran pemrograman dasar dengan model kooperatif tipe STAD berlatar musik klasik.

\section{Kajian Teori}

\section{Belajar}

Definisi belajar menurut Abdillah (Aunurrahman, 2012:35) adalah usaha sadar yang dilakukan oleh individu dalam perubahan tingkah 
laku baik melalui latihan dan pengalaman yang menyangkut aspek-aspek kognitif, afektif, dan psikomotorik untuk memperoleh tujuan tertentu. Dalam pelaksanaan belajar menurut Wragg (Aunurrahman, 2012:35) belajar memiliki beberapa ciri umum (1) belajar merupakan suatu aktivitas dari diri seseorang yang didasari atau disengaja. (2) Belajar merupakan interaksi individu dengan lingkungannya. (3) Hasil belajar ditandai dengan perubahan tingkah laku.

\section{Kompetensi}

Mulyasa (2013:66) kompetensi adalah penguasaan terhadap suatu tugas, keterampilan, sikap, dan apresiasi yang diperlukan untuk menunjang keberhasilan. Karakteristik dasar kompetensi dapat digolongkan menjadi lima tipe yaitu motif, watak, konsep diri, pengetahuan, dan keterampilan. (Amri \& Poerwati, 2013:172). Berdasarkan panduan penilaian pada sekolah menengah kejuruan pada tahun 2015, kompetensi pada kurikulum 2013 mencakup kompetensi dalam ranah kognitif, psikomotorik, dan afektif.

Ranah pengetahuan berhubungan dengan hasil belajar intelektual yang terdiri dari enam Aspek yakni mengingat, memahami menerapkan, menganalisis, mengevaluasi, dan menciptakan. Ranah keterampilan berhubungan kemampuan peserta didik dalam melaksanakan tugas praktik. Kompetensi keterampilan dapat diukur dengan menggunakan kata operasional mengidentifikasi, menghitung, membedakan, menyimpulkan, menceritakan kembali, mempraktikan, mendemonstrasikan, mendeskripsikan. Ranah afektif berhubungan dengan perkembangan sikap sosial siswa dalam menghargai, menghayati, dan berperilaku jujur, disiplin, tanggung jawab, peduli (toleransi, gotong royong), santun, percaya diri, dalam berinteraksi secara efektif dengan lingkungan sosial dan alam dalam jangkauan pergaulan dan keberadaanya.

Tabel 1. Predikat Capaian Kompetensi Afektif

\begin{tabular}{ll}
\hline Predikat & Rentang nilai \\
\hline Sangat Baik (A) & $86-100$ \\
Baik (B) & $71-85$ \\
Cukup (C) & $56-70$ \\
Kurang (D) & $\leq 55$ \\
\hline
\end{tabular}

Sumber : Kemendikbud (2015:89)

\section{Model Kooperatif Tipe STAD}

Mulyasa (2013:13) berpendapat "model belajar mengajar adalah kerangka konseptual dan prosedur yang sistematik dalam mengorganisasikan pengalaman belajar untuk mencapai tujuan belajar tertentu, berfungsi sebagai pedoman bagi perancang pengajaran, serta guru dalam merencanakan dan melaksanakan aktivifitas belajar mengajar.". Woolfolk (2001) dalam Warsono dan Hariyanto(2012:161) mendefinisikan pembelajaran kooperatif adalah suatu pengaturan yang memungkinkan para siswa bekerja sama dalam suatu kelompok campuran dengan kecakapan yang berbeda-beda, dan akan memperoleh penghargaan jika kelompoknya mencapai suatu keberhasilan.

Slavin (2005:143) menyatakan STAD merupakan salah satu metode pembelajaran kooperatif yang paling sederhana, dan merupakan model paling baik untuk tahap permulaan bagi guru yang baru menggunakan pendekatan kooperatif. Semua model pembelajaran kooperatif ditandai dengan adanya struktur tugas, struktur tujuan dan struktur penghargaan. Slavin (2005:12) mengungkapkan bahwa gagasan utama dari STAD adalah untuk memotivasi peserta didik supaya saling mendukung dan membantu satu sama lain dalam menguasai kemampuan yang diajarkan oleh guru. Jika peserta didik menginginkan agar timnya atau kelompoknya mendapatkan penghargaan maka peserta didik harus saling membantu untuk memahami materi. Slavin (2005:143-146) mengungkapkan bahwa STAD terdiri dari lima komponen utama yaitu presentasi kelas, tim, kuis, skor kemajuan individual, dan rekognisi tim. Dalam presentasi kelas, pertama-tama materi akan diperkenalkan oleh guru. Pada komponen ini merupakan pengajaran langsung yang dipimpin oleh guru ataupun dengan presentasi audiovisual. Komponen selanjutnya adalah pembagian tim atau kelompok. Tim terdiri empat atau lima peserta didik yang mewakili seluruh bagian kelas dalam hal prestasi akademik, jenis kelamin, golongan dan etnisitas. Kuis merupakan komponen selanjutnya dimana peserta didik akan mengerjakan kuis secara individual. Peserta didik tidak boleh saling membantu walaupun sebelumnya satu kelompok. Sehingga tiap peserta didik memiliki tanggung jawab sendiri-sendiri terhadap pemahaman materi.

Komponen selanjutnya adalah skor kemajuan individual. Pada komponen ini bertujuan untuk memberikan kepada setiap siswa penghargaan bila peserta didik belajar dengan giat dan memberikan kinerja yang lebih baik dari sebelumnya. Tiap siswa diberikan skor awal yang diperoleh dari rata-rata kinerja siswa sebelumnya dalam mengerjakan kuis yang sama. 
Tabel 2. Skor kemajuan

\begin{tabular}{ll}
\hline Skor Kuis & $\begin{array}{l}\text { Skor } \\
\text { Kemajuan }\end{array}$ \\
\hline $\begin{array}{l}\text { Lebih dari 10 poin dibawah } \\
\text { skor awal }\end{array}$ & 5 \\
10-1 poin dibawah skor awal & 10 \\
$\begin{array}{l}\text { Skor awal sampai 10 poin } \\
\text { diatas skor awal }\end{array}$ & 20 \\
$\begin{array}{l}\text { Lebih dari 10 poin diatas } \\
\text { skor awal }\end{array}$ & 30 \\
$\begin{array}{l}\text { Kertas jawaban sempurna } \\
\text { (terlepas dari skor awal) }\end{array}$ & 30 \\
\hline
\end{tabular}

Slavin (2005:159)

Komponen terakhir adalah rekognisi tim. Pada komponen ini, tim akan mendapatkan penghargaan apabila skor rata-rata tim mencapai kriteria tertentu.

Tabel 3. Kriteria penghargaan tim

\begin{tabular}{ll}
\hline Kriteria & Penghargaan \\
\hline 15 & Tim Baik \\
16 & Tim Sangat \\
& Baik \\
17 & Tim Super \\
\hline & Slavin (2005:160)
\end{tabular}

\section{Pembelajaran dengan Musik Klasik}

Dhority dalam DePorter, Reardon, dan Nourie (2008: 66) menyatakan segala sesuatu dalam lingkungan kelas menyampaikan pesan yang memacu atau menghambat belajar. Lingkungan kelas menurut DePorter, Reardon, dan Nourie (2008: 66) dapat dihias dengan berbagai cara menempel poster ikon, menempel poster afirmasi, menulis kata mutiara menggunakan warna, alat bantu, pengaturan bangku, tumbuhan, aroma, hewan peliharaan, dan musik.

Musik klasik merupakan salah satu aliran musik yang dapat meningkatkan konsentrasi anak. Campbell(2002:97) berpendapat "musik klasik (Haydn dan Mozart) memiliki kejernihan, keanggunan, dan kebeningan. Musik ini mampu memperbaiki konsentrasi, ingatan, dan persepsi spasial". DePorter (2008, 73) menyatakan "Penelitian yang mendukung penggunaan ... musik klasik (Satie, Rachmaninoff) untuk merangsang dan mempertahankan lingkungan belajar optimal. Wolfgang Amadeus Mozart atau Mozart merupakan salah satu komponis musik klasik. Musik klasik hasil karyanya sering disebut dengan musik mozart. Penelitian Castillo,dkk (2014:73:83) bahwa musik klasik dapat meningkatkan kemampuan keterampilan penalaran serta dapat memperbaiki konsentrasi.

\section{Pemrograman Dasar}

Mata pelajaran pemrograman dasar merupakan salah satu mata pelajaran dalam kelompok mata pelajaran dasar bidang keahlian teknologi informasi dan komunikasi. Kompetensi kognitif yang akan dicapai pada penelitian adalah kompetensi dasar 3.7 yaitu menerapkan struktur kontrol perulangan dalam bahasa pemrograman. Pada kompetensi dasar 3.7 tersebut peserta didik diharapkan dapat membuat rancangan atau sketsa alur program dengan menggunakan struktur kontrol perulangan. Kompetensi psikomotorik yang akan dicapai adalah kompetensi dasar 4.7 yaitu memecahkan masalah menggunakan struktur kontrol perulangan. Pada kompetensi 4.7 peserta didik diharapkan dapat membuat pemecahan masalah sehingga dapat diimplementasikan kedalam bahasa pemrograman dengan struktur kontrol peruangan.

\section{METODE PENELITIAN}

Penelitian ini merupakan penelitian tindakan kelas dengan pelaksanaan selama 2 siklus. Penelitian ini menggunakan model kooperatif tipe STAD dengan latar musik klasik. Subjek penelitian tindakan kelas ini adalah peserta didik kelas X Multimedia 1 di SMK Negeri 3 Surakarta tahun ajaran 2015/ 2016 pada semester genap. Jumlah peserta didik di kelas X Multimedia 1 sebanyak 32 peserta didik. Objek penelitian adalah kompetensi peserta didik pada mata pelajaran pemrograman dasar. Penelitian berlangsung pada bulan April sampai Mei 2016 selama dua siklus dan setiap siklusnya dilakukan selama 4 jam pelajaran. Data yang dibutuhkan pada penelitian adalah (1) data kompetensi peserta didik dalam ranah kognitif, psikomotorik, dan afektif. (2) data konsentrasi dan ketenangan peserta didik. (3) Jumlah peserta didik kelas X Multimedia 1. (4) Metode guru dalam menyampaikan materi. (5) Sikap siswa saat menerima materi dari guru.

Teknik yang digunakan oleh peneliti untuk mengumpulkan data baik data primer maupun sekunder adalah (1) Teknik Observasi digunakan untuk memperoleh data tentang metode guru dalam menyampaikan materi pemrograman dasar dan sikap atau respon peserta didik dalam 
pembelajaran. (2) Teknik dokumentasi digunakan untuk memperoleh data kompetensi siswa dalam aspek kognitif, psikomotorik, dan afektif pada survei. (3) Teknik wawancara digunakan untuk mengetahui respon dari guru terhadap pra penelitian terhadap proses belajar mengajar. (4) Teknik tes digunakan untuk mengetahui kompetensi siswa pada pra maupun pasca penelitian. (5) Teknik kuisioner digunakan untuk mendapatkan data efektivitas pemutaran musik klasik terhadap ketenangan dan konsentrasi. Data yang dibutuhkan oleh peneliti meliputi tiga ranah kompetensi, ranah kognitif, ranah psikomotorik, dan ranah afektif. Dari ketiga ranah tersebut ranah kognitif dan ranah psikomotorik yang menggunakan teknik pengumpulan data dengan tes, sedangkan ranah afektif menggunakan teknik pengumpulan data dengan observasi. Uji validasi data yang digunakan peneliti adalah uji triangulasi data dan validasi pakar ( expert judgement ). Untuk menganalisis pada penelitian ini, peneliti menggunakan teknik analisis data diskriptif komparatif.

Dalam penelitian ini indikator capaian yang ditetapkan oleh peneliti dengan guru mata pelajaran dalam aspek kognitif pada kompetensi dasar 3.7 adalah $70 \%$ peserta didik mendapatkan nilai minimal 70 , afektif adalah $70 \%$ peserta didik mendapatkan predikat minimal baik, maupun psikomotorik pada kompetensi dasar 4.7 adalah $70 \%$ peserta didik mendapatkan nilai minimal 70 .

\section{HASIL PENELITIAN}

\section{Pratindakan}

Pratindakan dilaksanakan pada tanggal 13 April 2016 pada jam 13.05 sampai 14.25 dengan 30 peserta didik yang mengikuti pembelajaran. Dua peserta didik lainnya yaitu Septiana Ika Wulandari $\mathrm{T}$ dan Shandy Setyawan tidak mengikuti pelajaran dikarenakan sakit. Guru dan peneliti merancang instrumen tes untuk mendapatkan data awal tentang kompetesi kognitif peserta didik. Hasil kompetensi kognitif dapat disimpulkan pada Tabel 4.

Tabel 4. Presentase Ketuntasan Kompetensi Kognitif pada Pratindakan

\begin{tabular}{ll}
\hline Keterangan & Presentase \\
\hline Lulus & $0 \%$ \\
Belum Lulus & $100 \%$ \\
\hline
\end{tabular}

Pada tabel diatas menunjukkan tidak ada peserta didik yang mendapatkan nilai lebih dari indikator kelulusan. Untuk mendapatkan data awal kompetensi psikomotorik, guru dan peneliti menyusun instrumen lembar kerja. Hasil kompetensi psikomotorik dapat disimpulkan pada Tabel 5.

Tabel 5. Presentase Ketuntasan Kompetensi Psikomotorik pada Pratindakan

\begin{tabular}{ll}
\hline Keterangan & Presentase \\
\hline Lulus & $33.33 \%$ \\
Belum Lulus & $66.67 \%$ \\
\hline
\end{tabular}

Pada tabel diatas menunjukkan peserta didik yang dapat nilai lebih dari indikator lulusan sebanyak $33.33 \%$. Untuk mendapatkan data awal pada kompetensi afektif, guru dan peneliti menyusun instrumen penilaian sikap spiritual dan sosial yang mengacu pada silabus mata pelajaran pemrograman dasar.

Tabel 6. Presentase Ketuntasan Kompetensi Afektif pada Pratindakan

\begin{tabular}{ll}
\hline Keterangan & Presentase \\
\hline Lulus & $40 \%$ \\
Belum Lulus & $60 \%$ \\
\hline
\end{tabular}

Pada tabel diatas menunjukkan pseserta didik yang dapat nilai lebih dari indikator lulusan sebanyak $40 \%$

\section{Siklus Pertama}

Siklus pertama dilaksanakan selama dua pertemuan, yaitu pertemuan pertama pada tanggal 20 April 2016 dan pertemuan kedua pada tanggal 11 Mei 2016. Materi pokok yang disampaikan pada siklus pertama pertemuan pertama adalah perulangan dengan kondisi di awal dan di akhir. Materi yang disampaikan pada pertemuan kedua siklus pertama masih sama dengan pertemuan pertama tetapi diberi variasi berupa kombinasi struktur kontrol perulangan dengan kondisi di awal dan di akhir dengan struktur kontrol percabangan dengan dua kondisi. Selain penentuan kompetensi dasar, guru dan peneliti menetapkan rencana pelaksanaan pembelajaran.

Guru dan peneliti menyiapkan (1) instrumen soal kuis untuk pertemuan pertama siklus pertama. Instrumen kuis pertemuan pertama siklus pertama berjumlah sepuluh soal kognitif yang diambil dari soal pratindakan dan siklus pertama. (2) instrumen kuis yang digunakan pada kuis pertemuan kedua siklus pertama berjumlah dua puluh soal kompetensi ranah kognitif. (3) instrumen penilaian psikomotorik. (4) instrumen afektif. Semua instrumen yang digunakan pada 
siklus pertama pertemuan pertama sudah divalidasi oleh ahli Pelaksanaan penelitian tindakan kelas pada pertemuan pertama siklus pertama tanggal 20 April 2016 pada jam 13.05 sampai 14.25 dengan peserta didik yang masuk berjumlah 32 peserta didik. Kegiatan pertama yang dilakukan guru adalah membuka pertemuan, dilanjutkan dengan mengecek kehadiran peserta didik. Sesi selanjutnya, guru penyampaian kompetensi yang akan dicapai pada pertemuan pertama siklus pertama. Pada tahap ini musik klasik mulai diperdengarkan. Tahap selanjutnya masuk komponen inti, dimana pada model kooperatif tipe STAD terdiri dari 5 komponen pokok. Tahap yang pertama, sebelum melakukan presentasi, guru terlebih dulu memancing ingatan peserta didik akan algoritma perulangan yang pernah dipelajari di semester gasal. Selanjutnya guru menyampaikan materi pokok pada pertemuan pertama siklus pertama.

Tahap yang kedua adalah penentuan tim. Dalam penentuan tim, guru membagi peserta didik berdasarkan nilai kompetensi kognitif hasil pratindakan. Pada tahap ini, peserta didik diberikan perintah untuk membuat program dengan menggunakan struktur kontrol perulangan dengan kondisi di awal dan di akhir dalam bahasa pemrograman pascal. Setelah selesai dengan pembelajaran dengan menggunakan metode kelompok atau tim, pada tahap berikutnya dari sepuluh kelompok dipecahmenjadi individuindividu. Komponen ini adalah kuis, dimana peserta didik secara individual mengerjakan kuis. Setelah selesai dengan kuis, guru melakukan perhitungan kemajuan individu dilihat dari perubahan hasil kompetensi kognitif pada pratindakan dengan hasil kuis pertemuan pertama. Pada implementasi lapangan, perhitungan kemajuan individu tidak bisa dilakukan secara maksimal karena waktu pembelajaran pemrograman dasar telah berakhir.

Pelaksanaan penelitian tindakan kelas pada pertemuan kedua siklus pertama tanggal $11 \mathrm{Mei}$ 2016 pada jam 13.05 sampai 14.25 dengan peserta didik yang masuk berjumlah 27 peserta didik. Kegiatan pertama yang dilakukan guru adalah membuka pertemuan, dilanjutkan dengan mengecek kehadiran peserta didik. Pada tahap ini musik klasik mulai diperdengarkan. Musik klasik yang diperdengarkan adalah karya Mozart volume 5. Tahap selanjutnya masuk komponen inti, dimana pada model kooperatif tipe STAD terdiri dari 5 komponen pokok. Pada tahap pertama, sebelum melakukan presentasi, guru terlebih dulu memancing ingatan dari peserta didik materi pada pertemuan sebelumnya. Selanjutnya guru menyampaikan materi pokok pada pertemuan kedua siklus pertama.

Komponen selanjutnya adalah penentuan tim. Dalam penentuan tim, guru membagi peserta didik berdasarkan nilai kuis pertemuan pertama. Pada komponen tim, disampaikan permasalahan atau soal yang harus dipecahkan oleh peserta didik. Komponen selanjutnya adalah kuis, dimana peserta didik secara individual mengerjakan kuis. Setelah selesai dengan kuis, guru melakukan perhitungan kemajuan individu dilihat dari hasil kompetensi kognitif pada hasil kuis pertemuan pertama dengan hasil kuis pertemuan kedua. Hasil dari kompetensi kognitif siklus pertama dapat disimpulkan pada Tabel 7.

Tabel 7. Persentase Kelulusan Kompetensi Kognitif Siklus Pertama

\begin{tabular}{ll}
\hline Keterangan & Presentase \\
\hline Lulus & $18.518 \%$ \\
Belum Lulus & $81.482 \%$ \\
\hline
\end{tabular}

Dari Tabel 7 memperlihatkan peserta didik yang lulus sesuai dengan indikator sebanyak $18.518 \%$. Kecapaian pada kompetensi kogitif masih jauh dari indikator keberhasilan. Hasil dari kompetensi psikomotorik siklus pertama dapat disimpulkan pada Tabel 8.

Tabel 8. Presentase Kelulusan Kompetensi Psikomotorik Siklus Pertama

\begin{tabular}{ll}
\hline Keterangan & Presentase \\
\hline Lulus & $74.074 \%$ \\
Belum Lulus & $25.926 \%$ \\
\hline
\end{tabular}

Dari Tabel 8 memperlihatkan peserta didik yang lulus sesuai dengan indikator kelulusan hanya $74.074 \%$. Pencapaian pada kompetensi psikomotorik sudah mencapai indikator. Hasil dari kompetensi afektif siklus pertama dapat disimpulkan pada Tabel 9.

Tabel 9. Presentase Kelulusan KopetensiAfektif pada Siklus Pertama

\begin{tabular}{ll}
\hline Keterangan & Presentase \\
\hline Lulus & $53.125 \%$ \\
Belum Lulus & $46.875 \%$ \\
\hline
\end{tabular}

Tabel 9 menunjukkan bahwa pada siklus pertama peserta didik yang lulus sesuai dengan indikator hanya $53.125 \%$. Kompetensi afektif peserta didik 
pada siklus pertama masih belum mencapai indikator keberhasilan penelitian.

Pelaksanaan siklus pertama terdapat beberapa kekurangan seperti (1) Guru dalam proses pembelajaran belum melaksanakan beberapa aspek di RPP seperti memfasilitasi peserta didik untuk merangkum materi pelajaran, memfasilitasi dan membimbing peserta didik untuk merefleksikan proses pembelajaran.. (2) Terdapat komponen STAD yang tidak terlaksana yaitu komponen rekognisi tim dan penilaian kemajuan individu yang tidak selesai dalam pembelajaran. (3) Peserta didik masih kurang aktif dalam menjawab pertanyaan dan bertanya. (4) Peserta didik dalam pembelajaran masih kurang konsentrasi. (5) Ketepatan waktu peserta didik dalam mengikuti pelajaran masih kurang.

\section{Siklus Kedua}

Pada tahap perencanaan siklus kedua, guru dan peneliti sebagai mitra kolabolator menentukan materi pokok pada pertemuan pertama siklus kedua adalah perulangan dengan pernyataan continue dan break. Selain penentuan kompetensi dasar dan materi pokok, guru dan peneliti menetapkan rencana pelaksanaan pembelajaran yang selanjutnya disebut RPP. Guru dan peneliti menyiapkan beberapa instrumen yang digunakan pada siklus kedua (1) soal kuis untuk pertemuan pertama siklus kedua. (2) Instrumen untuk penilaian kompetensi afektif. (3) Instrumen untuk penilaian dan soal kompetensi psikomotrik. (4) Instrumen kuisioner untuk menilai konsentrasi dan ketenangan peserta didik. Semua instrumen yang digunakan pada siklus kedua pertemuan pertama sudah divalidasi oleh ahli.

Pelaksanaan penelitian tindakan kelas pada pertemuan pertama siklus kedua tanggal 24 Mei 2016 pada jam 12.25 sampai 14.25 dengan peserta didik yang masuk berjumlah 30 peserta didik. Kegiatan pertama yang dilakukan guru adalah membuka pertemuan, dilanjutkan dengan mengecek kehadiran peserta didik. Pada sesi ini musik klasik karya Mozart volume 5 mulai diperdengarkan. Tahap selanjutnya masuk komponen inti, dimana pada model kooperatif tipe STAD terdiri dari 5 komponen pokok. Tahap yang pertama, sebelum melakukan presentasi, guru terlebih dulu memancing ingatan dari peserta didik akan materi pada pertemuan sebelumnya.

Komponen selanjutnya adalah penentuan tim. Dalam penentuan tim, guru membagi peserta didik berdasarkan nilai kompetensi kognitif pada siklus pertama. Pada komponen tim, disampaikan permasalahan yang harus dipecahkan oleh peserta didik. Setelah selesai kuis, guru melakukan perhitungan kemajuan individu dilihat dari hasil kompetensi kognitif pada siklus pertama dengan hasil kompetensi kognitif pada siklus kedua. Komponen terakhir adalah rekognisi tim dimana guru memberikan penghargaan kepada tim dengan kriteria kemajuan tertentu. Hasil dari kompetensi kognitif siklus kedua dapat disimpulkan pada Tabel 10.

Tabel 10. Presentase Kelulusan Kompetensi Kognitif Siklus Kedua

\begin{tabular}{cc}
\hline Keterangan & Presentase \\
\hline Lulus & $10 \%$ \\
Belum & $90 \%$ \\
Lulus & \\
\hline
\end{tabular}

Tabel 10 menunjukkan persentase peserta didik yang lulus sesuai indikator hanya $10 \%$. Kecapaian pada kompetensi kogitif masih jauh dari indikator keberhasilan. Hasil dari kompetensi psikomotorik siklus kedua dapat disimpulkan pada Tabel 11.

Tabel 11. Presentase Kelulusan Kompetensi Psikomotorik Siklus Kedua

\begin{tabular}{lc}
\hline Keterangan & Presentase \\
\hline Lulus & $76.67 \%$ \\
Belum Lulus & $23.33 \%$ \\
\hline
\end{tabular}

Dari Tabel 11, didapatkan kesimpulan bahwa kompetensi psikomotorik peserta didik yang lulus hanya $76.67 \%$. Pada siklus kedua, kompetensi psikomotorik peserta didik sudah melampaui indikator. Hasil dari kompetensi afektif siklus kedua dapat disimpulkan pada Tabel 12.

Tabel 12. Presentase Kelulusan Kompetensi Afektif pada Siklus Kedua

\begin{tabular}{ll}
\hline Keterangan & Presentase \\
\hline Lulus & $80 \%$ \\
Belum Lulus & $20 \%$ \\
\hline
\end{tabular}

Dari Tabel 12 peserta didik yang mencapai indikator kelulusan sebanyak $80 \%$. Kompetensi peserta didik ranah afektif pada siklus kedua sudah mencapai indikator keberhasilan. Pelaksanaan siklus pertama terdapat kelebihan seperti (1) semua komponen pada model kooperatif tipe STAD dapat dilaksanakan semua. (2) Penguasaan kelas pada siklus kedua lebih baik. (3) Guru senantiasa melontarkan pertanyaan, ataupun memancing peserta didik untuk 
menjawab. Terdapat beberapa kekurangan seperti (1) Pada komponen perhitungan kemajuan individu dan rekognisi tim, peserta didik mulai tidak kondusif. (2) Kejujuran peserta didik dalam pengerjaan tugas kurang. (3) Keaktifan peserta didik untuk bertanya masih kurang. (4) Waktu untuk latihan soal tidak ada

\section{Perbandingan Antar Siklus}

Berdasarkan hasil dari penelitian, didapatkan hasil berupa kompetensi kognitif, kompetensi psikomotorik, dan kompetensi afektif pada pratindakan, siklus pertama dan kedua serta hasil angket tentang efektivitas musik klasik terhadap ketenangan dan konsentrasi pada siklus pertama dan siklus kedua. Berikut merupakan perbandingan hasil kompetensi kognitif terhadap presentase kelulusan setiap siklus. Perbandingan tersebut dapat dilihat pada Tabel 13.

Tabel 13.Perbandingan Persentase Kompetensi Kognitif

\section{Presentase}

\begin{tabular}{llll}
\hline Ket & Pratindakan & Siklus I & Siklus II \\
\hline Lulus & $0 \%$ & $18.518 \%$ & $10 \%$ \\
$\begin{array}{l}\text { Belum } \\
\text { Lulus }\end{array}$ & $100 \%$ & $81.482 \%$ & $90 \%$ \\
\hline
\end{tabular}

Pada kompetensi kognitif belum tercapai sesuai indikator penelitian. Perubahan antarsiklus cenderung fluktuatif dengan perubahan positif dari pratindakan ke siklus pertama, sedangkan perubahan negatif dari siklus pertama ke siklus kedua. Perbandingan hasil kompetensi psikomotorik terhadap presentase kelulusan setiap siklus. Perbandingan tersebut dapat dilihat pada Tabel 14.

Tabel 14.Perbandingan Persentase Kompetensi Psikomotorik

\begin{tabular}{llll} 
& \multicolumn{3}{c}{ Persentase } \\
\cline { 2 - 4 } Ket & Pratindakan & Siklus I & Siklus II \\
\hline Lulus & $33.33 \%$ & $74.074 \%$ & $76.67 \%$ \\
$\begin{array}{l}\text { Belum } \\
\text { Lulus }\end{array}$ & $66.67 \%$ & $25.926 \%$ & $23.33 \%$ \\
\hline
\end{tabular}

Kompetensi psikomotorik antarsiklus mengalami peningkatan. Peningkatan yang paling besar dari pratindakan ke siklus pertama atau tindakan dengan perlakuan khusus. Dengan hasil ini kompetensi psikomotorik sudah melebihi indikator ketercapaian penelitian. Berikut merupakan perbandingan kelulusan pada kompetensi afektif dapat dilihat pada Tabel 15.

Tabel 15.Perbandingan Persentase Kompetensi Afektif

\section{Presentase}

\begin{tabular}{|c|c|c|c|}
\hline Ket & Pratindakan & Siklus I & Siklus II \\
\hline Lulus & $40 \%$ & $53.125 \%$ & $80 \%$ \\
\hline $\begin{array}{l}\text { Belum } \\
\text { Lulus }\end{array}$ & $60 \%$ & $46.875 \%$ & $20 \%$ \\
\hline \multicolumn{4}{|c|}{$\begin{array}{l}\text { Kompetensi afektif antarsiklus mengalami } \\
\text { peningkatan. Peningkatan yang paling besar dar } \\
\text { siklus pertama ke siklus kedua. Dengan hasil in } \\
\text { kompetensi afektif sudah melebihi indikato } \\
\text { ketercapaian penelitian. Dampak musik klasik } \\
\text { peraspek antarsiklus dapat dilihat pada Tabel } 16 . \\
\text { Tabel 16. Dampak Musik Klasik } \\
\text { T }\end{array}$} \\
\hline & Keterangan & Siklus I & Siklus II \\
\hline & Konsentrasi & 3.43 & 2.62 \\
\hline & Ketenangan & 3.18 & 2.52 \\
\hline
\end{tabular}

\section{PEMBAHASAN}

\section{Kognitif}

Pada pratindakan persentase peserta didik yang mencapai indikator $0 \%$, meningkat pada siklus pertama menjadi $18.518 \%$ dan pada siklus kedua menurun lagi menjadi $10 \%$.Kesimpulan kompetensi kognitif peserta didik di siklus kedua, belum mencapai indikator keberhasilan. Fenomena ini tidak sesuai dengan penelitian dari Haloho (2014:18-25) bahwa penggunaan model kooperatif tipe STAD dapat meningkatkan hasil belajar (ranah kognitif). Dalam penelitian dengan penerapan model kooperatif tipe STAD belum meningkatkan kompetensi peserta didik sesuai dengan indikator keberhasilan. Tentu saja hal tersebut tidak sesuai dengan tujuan penelitian. Penyebabnya dalam pembelajaran pada siklus kedua kuis belum maksimal sehingga peserta didik masih belum cukup latihan dalam pengerjaan kuis. Dalam pelaksanaan pembelajaran guru sudah memancing peserta didik untuk bertanya dan menjawab pertanyaan guru, tetapi peserta didik masih kurang aktif dalam merespon guru. 


\section{Psikomotorik}

Perubahan dari pratindakan ke siklus pertama dan dari siklus pertama ke siklus kedua mengalami peningkatan. Peningkatan dari 33.33 $\%$ pada pratindakan menjadi $74.074 \%$ pada siklus pertama dan pada siklus kedua meningkat menjadi $76.67 \%$. Peningkatan berdasarkan kriteria keberhasilan yang sudah ditetapkan. Kesimpulan kompetensi psikomotorik peserta didik pada pembelajaran menggunakan model kooperatif tipe STAD mengalami peningkatan sesuai dengan indikator keberhasilan. Senada dengan hasil penelitian Nurjanah, Suratno, \& Aprilya (2014: 114) bahwa model kooperatif tipe STAD dengan metode praktikum berpengaruh terhadap hasil belajar (ranah psikomotorik). Peningkatan kompetensi psikomotorik dikarenakan peserta didik dalam sesi diskusi memanfaatkan sesi tersebut dengan maksimal. Saling berdiskusi tentang cara untuk menyelesaikan masalah. Sehingga penguasaan terhadap tugas menjadi lebih baik.

\section{Afektif}

Peningkatan dari $40 \%$ pada pratindakan menjadi $53.125 \%$ pada siklus pertama dan pada siklus kedua meningkat menjadi $80 \%$. Perhitungan peningkatan berdasarkan kriteria keberhasilan ranah afektif. Keberhasilan ranah afektif bila peserta didik mendapatkan nilai lebih dari 70 atau mendapat predikat sikap baik. Kesimpulan pada kompetensi afektif, pembelajaran dengan menggunakan model kooperatif tipe STAD dapat meningkatkan kompetensi afektif peserta didik. Hal tersebut relevan dengan hasil penelitian Noerrudin (2014: 31- 41) bahwa penggunaan model kooperatif tipe STAD disertai umpan balik berbasis CTL mampu meningkatkan hasil belajar mahasiswa. Kompetensi afektif meningkat dengan diterapkannya model kooperatif tipe STAD karena dalam model tersebut peserta didik dituntut untuk aktif dalam pembelajaran. Guru hanya berperan sebagai fasilitator. Peserta didik dalam diskusi harus saling bantu dalam penguasaan materi. Hal ini yang menyebabkan sikap sosial peserta didik menjadi lebih baik.

\section{Musik Klasik}

Fenomena penggunaan musik klasik sebagai latar pembelajaran untuk memperbaiki konsentrasi dan ketenangan tidak sesuai dengan penelitian Castillo,dkk (2014:73:83) bahwa musik klasik dapat meningkatkan kemampuan keterampilan penalaran serta dapat memperbaiki konsentrasi. Namun dari hasil angket pada penelitian ini, skor konsentrasi dan kenyamanan pada siklus pertama dan siklus kedua mengalami penurunan. Dari hasil observasi penerapan musik klasik dalam pembelajaran direpon oleh peserta didik kurang baik karena kejenuhan dengan alunan musik klasik yang terlihat dari respon peserta didik yang meminta untuk mengganti jenis musik yang digunakan untuk latar pembelajaran. Hasil wawancara dengan beberapa peserta didik, ditemukan bahwa peserta didik lebih menyukai alunan musik modern seperti pop dan rock.

\section{SIMPULAN}

Berdasarkan hasil penelitian dapat disimpulkan (1) Penggunaan model kooperatif tipe STAD berlatar musik klasik belum dapat meningkatkan kompetensi kognitif peserta didik. (2) Penggunaan model kooperatif tipe STAD berlatar musik klasik dapat meningkatkan kompetensi psikomotorik peserta didik. (3) Penggunaan model kooperatif tipe STAD berlatar musik klasik dapat meningkatkan kompetensi afektif peserta didik. (4) Penggunaan musik klasik sebagai latar pembelajaran belum meningkatkan konsentrasi dan ketenangan peserta didik

\section{SARAN}

Berdasarkan hasil penelitian yang telah diperoleh, maka saran yang dapat digunakan sebagai tindak lanjut adalah (1) Peserta didik harus lebih aktif dalam pembelajaran seperti berani bertanya kepada guru, berani menjawab pertanyaan guru, dan berani mengungkapkan gagasan. (2) Penerapan model kooperatif tipe STAD memerlukan alokasi waktu yang tepat dan persiapan yang matang terhadap alur pembelajaran. (3) Penelitian yang lebih lanjut tentang upaya peningkatan kompetensi peserta didik menggunakan model kooperatif tipe STAD berlatar musik klasik dapat dilakukan lebih maksimal oleh peneliti yang lain.

\section{DAFTAR PUSTAKA}

.Undang-Undang Nomor 2 Tahun 1989 Tentang Sistem Pendidikan Nasional.

Amri, S. \& Poerwati, L.E. (2013). Panduan Kurikulum 2013,(Sebuah Inovasi Struktur Kurikulum Penunjang Masa Depan. Jakarta : Presasi Pustaka Publisher.

Aunurrahman. (2012). Belajar dan Pembelajaran. Bandung: Alfabeta. Campbell. D.(2002). Efek Mozart: Memanfaatkan Kekuatan Musik untuk Mempertajam Pikiran, Meningkatkan Kreativitas, dan 
Menyehatkan Tubuh. Jakarta: Gramedia Pustaka Utama.

Castillo,dkk. (2014). Effects of Music on the Spatial Reasoning Skills of Grade-One Pupils. International Journal of Learning, Teaching and Educational Research, 1(1), 73-83.

DePorter,B., Reardon ,M., \& Nourie, S.S. (2007). Quantum teaching: Mempraktikkan quantum learning di ruang-ruang kelas. Bandung: Mizan Pustaka.

Haloho(2014). Perbaikan Aktivitas belajar Biologi Siswa Melalui Penerapan Model Pembelajaran Kooperatif tipe STAD (Student Teams Achievement Division) Pada Siswa Kelas X-3 SMA Negeri 12 Medan. Jurnal Saintech, 6(2),18-25.

Kemendikbud. (2015). Panduan Penilaian Pada Sekolah Menengah Kejuruan. Jakarta:Kemendikbud.

Lamba,dkk.(2014).Impact of Teaching Time on Attention and Concentration. Journal of Nursing and Health Science, 3(4), 1-4.
Mulyasa. (2013). Pengembangan dan Implementasi Kurikulum 2013. Jakarta: Rosdakarya.

Noerrudin, A (2014). Implemantasi Model Pembelajaran Kooperatif Tipe STAD Disertai Pemberian Umpan Balik Berbasis Contextual Teaching And Learning (CTL) Untuk Meningkatkan Hasil Belajar Mahasiswa Pada Mata Kuliah Kalkulus Peubah Banyak IKIP PGRI Bojonegoro. Jurnal Ilmiah STKIP PGRI Ngawi, 13(1), 31-41.

Nurjanah, Suratno, \& Aprilya (2014). Pengaruh Model Pembelajaran STAD (Student Team Achievement Divisions) Dengan Metode Praktikum Terhadap Aktivitas dan Hasil Belajar Siswa Kelas XI SMA Negri 1 Purwoharjo-Banyuwangi Tahun Pelajaran 2011/2012. Pancaran, 3(1),1-14.

Slavin. R.E,. (2005). Cooperative Learning. Bandung: Nusa Media.

Warsono\&Hariyanto.(2012).Pembelajaran Aktif. Bandung: Remaja Rosdakarya. 